\title{
An education technique for discharge planning screening by nursing students: A descriptive study using a paper patient
}

\author{
Tsukasa Domoto ${ }^{* 1}$, Motoko Saneto ${ }^{2}$ \\ ${ }^{1}$ Japanese Red Cross Hiroshima College of Nursing, Hiroshima, Japan \\ ${ }^{2}$ Sonoda Women's University, Hyogo, Japan
}

Received: May 22, 2015

DOI: $10.5430 /$ jnep.v5n10p43

\author{
Accepted: July 8, 2015 \\ Online Published: July 26, 2015 \\ URL: http://dx.doi.org/10.5430/jnep.v5n10p43
}

\begin{abstract}
Objective: To clarify the relationships between items necessary for screening, nursing students extracted information from a description of a paper patient and considered means of developing assessment ability based on this information.

Methods: Design: Descriptive study. Setting: A Japanese nursing college. Participants: One hundred twenty-five sophomore students. Methods: Students performed an extraction of the information necessary for the discharge of a paper patient. We divided students' responses into two groups, those with and without extraction of information related to items of a discharge planning screening tool, and analyzed the relationships between items.

Results: "Movement" was associated with four items including "people living together", and "toileting" was associated with two items including "meal and water management". "People living together" was associated with five items including "family care", and "hope for a particular discharge destination" was associated with four items including "hope for a discharge plan" and "long-term care insurance". "Rehabilitation" was associated with "body cleansing". "Medication management" was not associated with any items, and "age" was not extracted.

Conclusions: Students required guidance in connecting patient and family information and expanding their knowledge to include family information, family care status, support systems, patients' and family members' intentions regarding life following discharge, and use of social resources. Patients should be encouraged to consider the care required to maintain health and activities of daily living following discharge and advised regarding postdischarge environmental changes and the features of old age. Therefore, teachers should include postdischarge environmental changes and the characteristics of old age in training content.
\end{abstract}

Key Words: Discharge planning, Education, Nursing students, Screening

\section{INTRODUCTION}

In recent years, with the rise in the number of older individuals in Japan, the demand for medical and nursing care has increased. To ensure efficient use of medical resources, classification of the functions of hospitals is promoted in Japan. The average duration of hospitalization in acute care hospitals has been reduced to 17.5 days. ${ }^{[1]}$ Therefore, in Japan, there was a tendency to discharge patients from the hospital once medical treatment was complete; however, many patients require the provision of medical procedures and continuous care at home subsequent to discharge. According to the revision of medical treatment fees in 2008, the receipt of medical treatment fees is dependent on the establishment of discharge planning departments. ${ }^{[2]}$ In 2012, extraction of

\footnotetext{
* Correspondence: Tsukasa Domoto; Email: tsukasadomoto@gmail.com; Address: Japanese Red Cross Hiroshima College of Nursing, 1-2 Ajinadai-Higashi, Hatsukaichi, Hiroshima Pref. 738-0052, Japan.
} 
information regarding patients requiring discharge planning and creation of a discharge plan within 7 days of hospitalization were implemented. ${ }^{[3]}$ In 2014, the function and role of hospitals was clarified, home reversion rates were determined for hospital wards, and regional comprehensive care wards were established. Further, regional comprehensive medical fees and practice have recently been implemented, and medical institutions' focus on home care was evaluated. These measures promote discharge from hospital to the home, and home care in Japan. ${ }^{[4]}$

Against this background, the rate at which discharge planning departments were established increased from $29.4 \%$ in 2001 to $73.2 \%$ in 2010 , and these departments employ staff members who specialize in discharge planning. ${ }^{[5]}$

In Japan, problems occur with respect to the omission of patients who require discharge planning, and delays in initiating such planning. ${ }^{[6]}$ Furthermore, an assessment of ward nurses' discharge planning screening found that understanding and attainment levels were lower in less experienced nurses. ${ }^{[7]}$ To address these problems, all ward nurses should assume the role of discharge planning coordinator and perform initial screening and assessment. ${ }^{[8]}$

To ensure effective screening by nurses, a discharge planning screening tool was developed to allow all nurses to perform assessments from the same perspective. ${ }^{[9]}$ With the introduction of the screening tool and conferences to discuss discharge, ward nurses' screening capacity is likely to improve. ${ }^{[10]}$ However, ward nurses create a number of documents during the patient's hospitalization. For this reason, some hospitals do not use a screening tool once ward nurses know which information is required for screening. Therefore, before nursing students undertake nursing duties, they should be aware of the information needed to screen patients who require discharge planning.

Due to attempts to reduce the average duration of hospitalization, there are more opportunities for lower-grade nursing students to assume responsibility for patients who require support and guidance with respect to discharge. Young's ideas, connections, and extensions (ICE) approach is a learning method in which ideas, connections, and extensions represent three different levels of learning growth from novice through to competence and expertise. Ideas are the fundamental, discrete pieces of information that make up the basics of new learning. Connections at the content level are demonstrated when students are able to articulate relationships between discrete ideas. At the extensions stage, new learning is created from old, allowing students to use it in novel and creative ways that may be quite far removed from the original learning context. Extensions are referred to by some as the "Aha!" phase of learning and by others as the "so what?" phase. ${ }^{[11]}$ This could offer effective guidance as to the associations between items required for discharge planning screening via hospital practice.

Comprehensive education programs to teach students about the transition from hospital to home have been established for medical students, ${ }^{[12]}$ pharmacy students, ${ }^{[13]}$ and ward nurses. ${ }^{[14]}$ However, as far as the authors are aware, no studies have been conducted to examine education methods specific to discharge planning screening conducted by nursing students. Therefore, we produced an easily understandable education technique for beginners, to reveal the relationships between the different types of assessment information required by nursing students, which was extracted from a description of a paper patient. As the participants in this study were lower-grade nursing students, this could also be applied to training regarding the collection of this information, for high-grade nursing students, staff nurses, and novice nurses.

The purpose of this study was to investigate the relationships between items required by nursing students for screening, for which information was extracted from a description of a paper patient. We also considered means of developing screening ability related to the items required for discharge planning screening.

\section{METHOD}

\subsection{Participants}

Participants were 125 students attending the first nursing process module of a course at a nursing college. Participants had previously attended courses that included information regarding the structure and function of the human body, supportive relationships that become the foundation for practice in nursing, assisting patients to perform daily activities, and acting as an auxiliary physician. In addition, they had completed four days of hospital practice to improve their understanding of patient recuperation via observation of a patient and provision of nursing assistance.

\subsection{Data collection}

\subsubsection{Data collection period}

We explained a homework exercise, which consisted of extracting information that was important for the paper patient's discharge, to the students on June 18, 2013, and they submitted their responses on July 2, 2013.

\subsubsection{Data collection method}

The paper patient was a woman in the recovery phase of rehabilitation subsequent to brain infarction (see Table 1). Understanding the nursing problem was one of the learning 
objectives. Therefore, we extracted information considered necessary for discharge planning in advance. Information regarding the paper patient was provided during a nursing process lecture, and students were asked to extract infor- mation that they believed would be required for discharge planning. We distributed a sheet on which students could record this information.

Table 1. Introduction of a paper patient

\begin{tabular}{|lll}
\hline \multicolumn{2}{l}{ Material: Paper Patient } \\
74 years old $\quad$ Female & Cerebral infarction & Admission date: 04.18.2013 \\
[Case Overview] & &
\end{tabular}

The patient experienced nausea and loss of strength early on the morning of April 18, 2013. Therefore, she and her family visited B Hospital. Following admission, drug therapy (intravenous) was initiated. There was paralysis (MMT: 3-4) present in her upper and lower right limbs. There was no joint contracture, but when the upper and lower right limbs were moved, she experienced mild pain. Rehabilitation was initiated for sequelae of cerebral infarction. She is able to walk slowly without assistance in her hospital room. She is fully conscious. She is able to understand questions, but there is evidence of a mild language disorder. Therefore, her speech is unclear; there are also times when she finds it difficult to hear. There are times when the conversation does not progress as intended, and she is less likely to expose her own thoughts. At the age of 50 years, she was diagnosed with high blood pressure. Since then, she has been taking amlodipine besilate $5 \mathrm{mg}$ (once daily). Her blood pressure has been stable (around 140/80 $\mathrm{mmHg}$ ). Her temperature ranges from $36.4^{\circ} \mathrm{C}$ to $36.8^{\circ} \mathrm{C}$ her pulse is $70-80 \mathrm{bpm}$, and her respiration rate is $16-20$ breaths per minute. Her current prescription drugs are candesartan cilexetil, 4 mg; aspirin, 100 mg (one tablet in the morning); and pravastatin sodium, $5 \mathrm{mg}$ (one tablet each morning and evening). She also uses glutathione eye drops, which are managed by nurses.

\section{[Present situation]}

Her insurance status is Support Required 2 (Long-term Care Insurance), the degree of independent living recorded for her is J-2, and her score on Hasegawa's Dementia Scale-Revised is 25 . She has gradually lost her willingness to engage in rehabilitation. She returned home for going out last week. However, she was unable to move as well as she expected with the walker. Until retirement, she was a high school teacher. Her husband is 77 years old and remains at home. He fell 10 years ago; he is finally able to walk and performs activities of daily living independently.

Her eldest daughter is unmarried. The journey from her house to the patient's home takes 10 minutes by car. In addition, she has visited the hospital 1-2 times per week. Her second-eldest daughter is married. She lives in another prefecture. She has visited the hospital with her two children once in 1-2 weeks. Family relationships are good.

\section{[Activities of daily living and Rehabilitation]}

Before she developed cerebral infarction, she was able to do the housework. She participated in a Haiku circle (twice per week). She shopped for more than 5 minutes every other day, using a cane for low back pain. She has a gregarious personality, but subsequent to the onset of the cerebral infarction, her facial expression no longer exudes her previous brightness. The patient's home is Japanese in style and has a second floor. She was sleeping on a futon. The toilet is Japanese in style. Because the bathtub is deep and there is no aid, bathing will be difficult following discharge.

Before admission, the patient regularly ate three meals per day. Because she chokes occasionally during meals, her staple food will be rice porridge, with side dishes chopped, subsequent to hospitalization. Her calorie intake is limited to 1,400 kcal per day, and her salt intake is restricted. Although she was right handed, she now eats by herself using a spoon or fork held in her left hand. It takes her 30 minutes to eat a meal. She eats $50 \%$ of both the staple food and side dish, and she drinks water thickened with gelatin. Her weight was $55 \mathrm{~kg}$ prior to admission. Her current weight is $52 \mathrm{~kg}$, and her height is $156 \mathrm{~cm}$.

She is not actively drinking water. She drinks one cup per meal (150 ml) and half a cup of water (75 ml) at 10:00 and 15:00. In addition, since staff members recommended that she increase her water intake, she has been drinking a cup of water following rehabilitation exercises. She has not complained of a dry mouth.

She brushes her teeth in bed after each meal. When her physical condition is good, she walks to the washroom using a walker, with assistance from a nurse. When she leaves her hospital room, she uses the walker. Walking is inconvenient, as there is some paralysis in her right foot, and she walks slowly. However, she is able to walk with a walker through the hospital wards without assistance. As she tends to watch her feet, she is slightly stooped while walking. Therefore, when she walks around the ward with the walker, she should be accompanied by a nurse. She is engages in rehabilitation with a physical therapist (PT) for 20-30 minutes per day from Monday to Friday. However, she is sometimes unable to attend rehabilitation due to her physical condition. Her rehabilitation entails five round trips consisting of walking $5 \mathrm{~m}$ using the parallel bars and a cane and walking with the assistance of a PT. As her momentum is reduced relative to that observed prior to admission, the amount of muscle on her unaffected side has also decreased. Sitting down on the side of a bed is manageable for her, and she can catch objects and stand for a short time. When she is not participating in rehabilitation, she often lies in bed.

In a conversation with the patient, an attending physician said, “Toward the discharge date, let's focus on rehabilitation and you'll do it on your own after discharge.” In a conversation with her eldest daughter, an attending physician said, "Recently, her willingness to attend rehabilitation has decreased, please encourage her. If it is difficult for her to go back home, she can continue rehabilitation at the rehabilitation hospital.” The patient's eldest daughter intends to talk to her soon about life following discharge. However, her daughter is worried that she does not express her wishes, as she does not want to be a burden. With regard to her body cleansing, nurses clean her body every day. Once per week, nurses plan a shower bath for her; however, she often refuses this. When the eldest daughter visited the hospital, she clipped the patient's nails. With respect to dressing, she can remove her jacket without assistance. However, she needs some assistance with fastening and unfastening her underwear. She wears pants for rehabilitation every day. There is urgency, but toileting takes a long time at night. As she may not make it to the toilet, she wears incontinence pads.

During the day, she walks to the toilet using a walker with the assistance of a nurse and uses a Western-style toilet. Because she almost fell one night, she uses a portable toilet at her bedside. She has refrained from pressing the nurse call button for help with excretion. She urinates 7-8 times daily (twice at night) and defecates once every 2 to 3 days (with defecation yesterday). If there is no defecation for three days, sennosides ( 1 tablet) is administered.

She is in a quadruple hospital room (entrance side). Her roommates pull their curtains closed during the day. She now has fewer opportunities to talk to her roommates.

She goes to bed at 22:00 and wakes up at 05:30. She tends to have a nap during the day. She uses reading glasses. There is some hearing loss in the right ear. 


\subsection{Ethical considerations}

This study was approved by the research ethics committee at the institution with which the researchers were affiliated (approval number: 1308). The data were obtained from the student responses recorded during data extraction and provided by the nursing process lecturer. We explained that the study procedures, including data extraction, were not subject to grading. During the students' final nursing process lecture, the principal researcher distributed consent forms and a document containing a description of the study purpose, a statement confirming the voluntary nature of study participation, and an assurance that students' course results would not be affected by refusal to participate. A researcher explained the study procedure verbally and asked students to sign an agreement permitting the use of the data resulting from their homework. Students who agreed to participate submitted signed written consent forms. Prior to performing the analysis, we replaced participants' names with randomly assigned identification numbers for use during the study, to ensure anonymity. Participants' personal details were stored in a lockable location.

\subsection{Data analysis methods}

Items from a Japanese screening tool designed for discharge planning ${ }^{[15]}$ were used, the validity and reliability of which have previously been established. Ten items were used to gather information regarding the patient's age, degree of assistance required for movement and toileting activities, cognition, family care, people living together, long-term care insurance, medical treatment and care required following discharge, and the patient's or family's hopes for a discharge plan and a particular discharge destination. Weighted point scoring was used for each item, and total scores ranged from 0 to 33. Patients who scored 10 or more points were considered high risk. Of 13 measures related to "medical treatment and care required following discharge", the following four aspects of treatment and care were identified for use with the paper patient: "rehabilitation", "medication management", "meal and water management", and "body cleansing". Using the description of the paper patient, two researchers, one of whom had experience as a nurse specializing in discharge planning, classified the information necessary to determine scores for the weighted points assigned to each item (see Table 2).

We divided students' homework responses into two groups: those for which extraction of information related to each item had been performed and those for which this procedure had not been performed. We analyzed the data using a chi-square test and Fisher's exact test for each item. SPSS software (Statistical Package for the Social Sciences, Version 22.0, Armonk, NY: IBM) was used to perform data analysis.

\section{RESULTS}

\subsection{Participants}

Of the 144 sophomore students who attended the nursing process lectures, we excluded data from 19 who refused to participate in the study upon receiving the description of the study procedure. We therefore analyzed data from 125 students.

\subsection{Extraction of information required for screening}

The proportions of students who extracted each item are shown in Table 3. Regarding the information related to each item of the screening tool, more than $60 \%$ of students extracted the following five items: "movement", "toileting", "rehabilitation", "meal and water management", and "body cleansing". In contrast, fewer than $60 \%$ of students extracted the remaining eight items of the screening tool. None of the students extracted "age" as information required in discharge planning.

\subsection{Associations between items extracted by students}

As "age" was not extracted, we analyzed the relationships between the 12 extracted items (see Table 4).

"Movement" was associated with "toileting", "people living together", "hope for a discharge plan", and "body cleansing", and "toileting" was associated with "movement" and "meal and water management". In addition, "cognition" was associated with "people living together", "family care", and "long-term care insurance".

"People living together" was associated with "movement", "cognition", "family care", "long-term care insurance", and "hope for a particular discharge destination." In addition, "family care" was associated with "cognition", "people living together", "hope for a discharge plan", and "long-term care insurance", and "hope for a discharge plan" was associated with "movement", "hope for a particular discharge destination", and "family care". "Long-term care insurance" was associated with "cognition", "people living together", and "family care", and "rehabilitation" was associated with "body cleansing". "Medication management" was not associated with any other items, but "meal and water management" was associated with "toileting". Further, "body cleansing" was associated with "movement" and "rehabilitation", and "hope for a particular discharge destination" was associated with "hope for a discharge plan" and "people living together". 
Table 2. Classification of paper patient information

\begin{tabular}{|c|c|}
\hline Item & Paper patient information \\
\hline Age & 74 years \\
\hline Movement & $\begin{array}{l}\text { She was unable to move at home using a walker as well as she expected. } \\
\text { When her physical condition is good, she goes to the washroom using the walker, with assistance. } \\
\text { When she walks with the walker in the ward, a nurse should accompany her. } \\
\text { During the day, the patient goes to the toilet using a walker, with the assistance of nurses. } \\
\text { Once, she almost fell during the night. }\end{array}$ \\
\hline Toileting & She requires some assistance with fastening and unfastening her underwear. \\
\hline Cognition & $\begin{array}{l}\text { She is fully conscious. } \\
\text { She is able to understand questions. } \\
25 \text { points on Hasegawa's Dementia Scale-Revised }\end{array}$ \\
\hline People living together & $\begin{array}{l}\text { She lives with her husband. } \\
\text { It takes her eldest daughter } 10 \text { minutes to travel from her house to the patient's home by car. } \\
\text { Her second-eldest daughter lives in another prefecture. }\end{array}$ \\
\hline Family care & $\begin{array}{l}\text { Her husband is } 77 \text { years old. } \\
\text { Her husband fell } 10 \text { years ago. } \\
\text { Her husband is finally able to walk and performs activities of daily living independently. }\end{array}$ \\
\hline Hope for a discharge plan & Eldest daughter is worried that the patient does not express her wishes. \\
\hline Long-term care insurance & Support Required: 2 \\
\hline Rehabilitation* & $\begin{array}{l}\text { Rehabilitation has been implemented for sequelae of cerebral infarction. } \\
\text { She engages in rehabilitation for } 20-30 \text { minutes per day from Monday to Friday. } \\
\text { Her rehabilitation entails } 5 \text { round trips consisting of walking } 5 \text { m using the parallel bars. } \\
\text { Her rehabilitation also involves walking with a cane and the assistance of a physical therapist. } \\
\text { Her momentum is reduced relative to that observed before admission. } \\
\text { The amount of muscle on her unaffected side has decreased. } \\
\text { She can catch objects and stand for a short time. }\end{array}$ \\
\hline Medication management* & $\begin{array}{l}\text { She has been taking amlodipine besilate, } 5 \mathrm{mg} \text { (once per day). } \\
\text { Candesartan cilexetil, } 4 \mathrm{mg} \text { and aspirin } 100 \mathrm{mg} \text { ( } 1 \text { tablet in the morning) } \\
\text { Pravastatin sodium, } 5 \mathrm{mg} \text { (one tablet each morning and evening) } \\
\text { Glutathione eye drops are managed by nurses. } \\
\text { If she does not defecate for three days, sennosides ( } 1 \text { tablet) is administered. }\end{array}$ \\
\hline $\begin{array}{l}\text { Meal and water } \\
\text { management* }\end{array}$ & $\begin{array}{l}\text { She sometimes chokes during a meal. } \\
\text { She drinks water with thickening. } \\
\text { Her staple food will be rice porridge with chopped side dishes following hospitalization. } \\
\text { Her calorie intake is restricted to 1,400 kcal, with a salt restriction. } \\
\text { She is not actively drinking water. } \\
\text { She drinks one cup per meal ( } 150 \mathrm{ml}) \text {. } \\
\text { She drinks half a cup of water ( } 75 \mathrm{ml}) \text { at 10:00 and 15:00. } \\
\text { Since staff members recommended that she increase her water intake, she has been drinking a cup of } \\
\text { water subsequent to rehabilitation. } \\
\text { She has not complained about a dry mouth. }\end{array}$ \\
\hline Body cleansing* & $\begin{array}{l}\text { Nurses clean her body every day. } \\
\text { Her eldest daughter clips the patient’s nails. }\end{array}$ \\
\hline $\begin{array}{l}\text { Hope for a particular } \\
\text { discharge destination }\end{array}$ & $\begin{array}{l}\text { An attending physician proposed that she could continue rehabilitation at the rehabilitation hospital. } \\
\text { Her eldest daughter intends to talk to the patient soon regarding life following discharge. }\end{array}$ \\
\hline
\end{tabular}

* Medical treatment and care required following discharge

\section{DiscuSSION}

\subsection{Patient information (Movement and Cognition)}

Surveys examining the indoor movement of elderly individuals must acknowledge that the distance from the bedroom to

Published by Sciedu Press the bathroom and toilet is further than that from the bedroom to the entrance and dining room, and the frequency with which individuals use the toilet is higher relative to the use of other rooms. ${ }^{[16]}$ With respect to "movement", we believe 
that, due to the ease with which nursing students imagined movement to the toilet and bathroom as activities of daily living, they associated "toileting" with "body cleansing".

Further, previous studies have found that family members feel responsible for ensuring that patients perform activities, such as walking, subsequent to discharge. ${ }^{[17]}$ Because nursing students were able to understand the influence of movement on life following discharge and were aware that this could lead to anxiety and worry in patients and their family members prior to discharge, it appears that they associated "movement" with "hope for a discharge plan."

Patients who experience a decline in cognition require support from others, which places a considerable physical and mental burden on caregivers. Therefore, the coordination of social resources is required as a means of supporting caregivers. ${ }^{[18]}$ We believe that the associations between "cognition" and "family care" and "long-term care insurance" reflect the need for social resources, as students examined the need for support from others following discharge in the context of their understanding of "cognition".

Both "movement" and "cognition" were associated with "people living together". In a survey of family caregivers in Japan, the proportion of care recipients and caregivers who lived together was $90.6 \% .^{[19]}$ We believe that students were aware that living with another person could increase the likelihood of support following discharge.

Table 3. Extraction of items required for screening $(n=125)$

\begin{tabular}{lll}
\hline Item & $\mathbf{n}$ & $\mathbf{\%}$ \\
\hline Age & 0 & 0.0 \\
Movement & 108 & 86.4 \\
Toileting & 79 & 63.2 \\
Cognition & 55 & 44.0 \\
People living together & 47 & 37.6 \\
Family care & 56 & 44.8 \\
Hope for a discharge plan & 72 & 57.6 \\
Long-term care insurance & 31 & 24.8 \\
Rehabilitation* & 106 & 84.8 \\
Medication management* & 40 & 32.0 \\
Meal and water management* & 120 & 96.0 \\
Body cleansing* & 75 & 60.0 \\
Hope for a particular discharge destination & 38 & 30.4 \\
\hline * Medil teatment and requed following & disch
\end{tabular}

* Medical treatment and care required following discharge

Table 4. Associations between the items necessary for screening

\begin{tabular}{|c|c|c|c|c|c|c|c|c|c|c|c|c|}
\hline & $\begin{array}{l}\text { Move- } \\
\text { ment }\end{array}$ & $\begin{array}{l}\text { Toilet- } \\
\text { ing }\end{array}$ & $\begin{array}{l}\text { Cogni- } \\
\text { tion }\end{array}$ & $\begin{array}{l}\text { People } \\
\text { living } \\
\text { together }\end{array}$ & $\begin{array}{l}\text { Family } \\
\text { care }\end{array}$ & $\begin{array}{l}\text { Hope for a } \\
\text { discharge } \\
\text { plan }\end{array}$ & $\begin{array}{l}\text { Long- } \\
\text { term } \\
\text { care } \\
\text { insurance }\end{array}$ & $\begin{array}{l}\text { Reha- } \\
\text { bilitation }^{\dagger}\end{array}$ & $\begin{array}{l}\text { Medica- } \\
\text { tion } \\
\text { manage- } \\
\text { ment }^{\dagger}\end{array}$ & $\begin{array}{l}\text { Meal and } \\
\text { water } \\
\text { manage- } \\
\text { ment }^{\dagger}\end{array}$ & $\begin{array}{l}\text { Body } \\
\text { clean- } \\
\text { sing }^{\dagger}\end{array}$ & $\begin{array}{l}\text { Hope for a } \\
\text { particular } \\
\text { discharge } \\
\text { destination }^{\dagger}\end{array}$ \\
\hline Movement & - & $0.002 *$ & 0.192 & $0.018^{*}$ & 0.170 & $0.045^{*}$ & $0.236 \neq$ & $0.723 \ddagger$ & 0.172 & $0.525 \ddagger$ & $0.025^{*}$ & 0.072 \\
\hline Toileting & & - & 0.929 & 0.620 & 0.331 & 0.190 & 0.861 & 0.997 & 0.061 & $0.006 * \ddagger$ & 0.082 & 0.995 \\
\hline Cognition & & & - & $0.000^{*}$ & $0.000^{*}$ & 0.630 & $0.000^{*}$ & 0.495 & 0.589 & $0.383 \ddagger$ & 0.270 & 0.094 \\
\hline $\begin{array}{l}\text { People } \\
\text { living } \\
\text { together }\end{array}$ & & & & - & $0.000^{*}$ & 0.729 & $0.000 *$ & 0.270 & 0.117 & $0.649 \ddagger$ & 0.291 & $0.022^{*}$ \\
\hline $\begin{array}{l}\text { Family } \\
\text { care }\end{array}$ & & & & & - & $0.037^{*}$ & $0.000^{*}$ & 0.807 & 0.423 & $1.000 \ddagger$ & 0.557 & 0.052 \\
\hline $\begin{array}{l}\text { Hope for a } \\
\text { discharge } \\
\text { plan }\end{array}$ & & & & & & - & 0.188 & 0.138 & 0.710 & $1.000 \ddagger$ & 0.301 & $0.000^{*}$ \\
\hline $\begin{array}{l}\text { Long-term } \\
\text { care } \\
\text { insurance }\end{array}$ & & & & & & & - & $0.154 \ddagger$ & 0.356 & $1.000 \ddagger$ & 0.554 & 0.246 \\
\hline $\begin{array}{l}\text { Rehabilita- } \\
\text { tion }^{\dagger}\end{array}$ & & & & & & & & - & 0.564 & $0.165 \ddagger$ & $0.000^{*}$ & 0.674 \\
\hline $\begin{array}{l}\text { Medication } \\
\text { manage- } \\
\text { ment }^{\dagger}\end{array}$ & & & & & & & & & - & $0.176 \ddagger$ & $1.000 \ddagger$ & $0.368 \ddagger$ \\
\hline $\begin{array}{l}\text { Meal and } \\
\text { water } \\
\text { manage- } \\
\text { ment }^{\dagger}\end{array}$ & & & & & & & & & & - & 0.388 & 0.639 \\
\hline $\begin{array}{l}\text { Body } \\
\text { cleansing }^{\dagger}\end{array}$ & & & & & & & & & & & - & 0.204 \\
\hline $\begin{array}{l}\text { Hope for a } \\
\text { particular } \\
\text { discharge } \\
\text { destination }^{\dagger}\end{array}$ & & & & & & & & & & & & - \\
\hline
\end{tabular}




\subsection{Family information}

Students may have associated "family care" with "people living together" in consideration of the likelihood that patients would receive support following discharge and felt the need to take discharge destinations other than home into account according to whether patients lived with another person.

In the Family Caregivers' Appraisal Checklist, family characteristics that allow continued home care are "balance between life and caregiving", "preparedness for emergencies", "positive appraisal of family caregiving", "family caregiver's roles", "family's economic status," "quality of care service," and "positive acceptance of home care". [20] Students may have associated "family care" with "hope for a discharge plan", because consideration of the family following discharge is important in the provision of care.

Caregivers can find that their ability to engage with their social networks is compromised. Therefore, consideration of the introduction of social services to ensure that family members are provided with some respite is necessary. ${ }^{[21]}$ Students were aware that the use of social resources could allow family members to continue to care for patients following discharge. This could be the reason that they associated "family care" with "long-term care insurance".

\subsection{Medical procedures and postdischarge care}

Elderly individuals' quality of life is reduced by loss of independence with respect to activity. ${ }^{[22]}$ Regarding the association between "rehabilitation" and "body cleansing", as students considered the protection of patients' privacy, particularly with respect to body cleansing, they would have emphasized independence following discharge.

With respect to the association between "meal and water management" and "toileting", the paper patient showed a tendency toward constipation. General factors contributing to constipation include dietary fiber, moisture, and exercise. ${ }^{[23]}$ Nursing students would have considered methods of promoting natural defecation, other than medicine management, to improve patients' daily lives. Therefore, we believe that they felt the need to consider methods associated with the ingestion of food and water for implementation following discharge. This indicates that they were able to associate healthcare needs with the medical treatment and care required following discharge. This association could be effective for patients with diabetes or hypertension.

\subsection{Teaching methods}

As means of developing screening ability based on the ICE approach, students recognize the information necessary for

Published by Sciedu Press screening at the ideas stage. Thereafter, in the connections phase, ideas are interpreted in relation to each piece of information. In the extension stage, students collect the information necessary to screen patients for discharge in clinical training and continue to progress toward judgment of the need for assistance.

Nursing students tend to emphasize information related to the patients on a personal level as information required for discharge. ${ }^{[24]}$ Therefore, it is necessary to enable students to connect different aspects of patient information and extend their knowledge regarding patients to encompass "people living together," aspects of the patient's physical and mental state such as those involving movement and cognition, and family care including details of support structures, patients' and family members' intentions regarding life following discharge, and the use of social resources. Further, to enable patients to maintain their health and activities of daily living subsequent to discharge, awareness of the association between the care required following discharge and care provided in the hospital is required.

With respect the lack of an association between "medication management" and other items, guidance that improves awareness of the purpose of medications, health management, and managing in an environment without medical staff is required. With respect to students' failure to extract "age" as necessary information, in a previous study involving nursing students, awareness of the physical characteristics of elderly individuals, such as reduced muscle strength and memory, increased once students had attended gerontological nursing training. ${ }^{[25]}$ As the nursing students in this study had not studied gerontological nursing, their understanding of the features of elderly patients was limited. However, we believe that nursing students' understanding could improve as they associate the physical characteristics of elderly patients with "cognition" and "movement" via contact with patients who require discharge planning in clinical practice.

\subsection{Limitations}

As a paper patient was used in this study, detailed information was provided in the description. In practice, nurses collect information required for discharge themselves and assess it within a short period, but as the information was provided and somewhat reduced, there was more time available for information extraction and collection.

Further studies should examine the collection of information required in discharge planning screening from hospital patients and investigate the effectiveness of education techniques. 


\section{Conclusion}

In this study, nursing students performed data extraction as a homework exercise to identify information required in discharge planning, using a paper patient case. The study aimed to examine the relationships between the items used in discharge planning screening by nursing students, which were extracted from the paper patient description. We also considered means of developing screening ability in the assessment of information required for discharge planning screening.

Results showed that patients' personal information, such as that regarding "movement" and "cognition", was associated with "people living together", which was associated with "long-term care insurance", "family care", and "hope of discharge planning". In addition, "rehabilitation" was related to "body cleansing", and "meal and water management" was associated with "toileting". "Medication management" was not associated with any items, and none of the students extracted "age" as necessary information.

In light of the above, it is necessary to expand students' knowledge regarding patients' information including details of the patient's status, family care situation, support system, patients' and family members' intentions regarding life following discharge, and use of social resources. In addition, the instruction that teachers provide for students should encompass the treatment and care received in the hospital, to ensure that students consider the treatment and care required following discharge, and patients are able to maintain activities of daily living and engage in health management. Patients should be encouraged to consider the care that will be required subsequent to discharge and advised regarding postdischarge environmental changes and the characteristics of old age, which teachers should also include in training content.

\section{ACKNOWLEDGEMENTS}

We wish to express our sincere thanks to the sophomore students who cooperated with us in our efforts by completing a homework exercise and providing the study data.

\section{CONFlicts of Interest Disclosure}

The authors declare that there is no conflict of interest statement.

\section{REFERENCES}

[1] Ministry of Health, Labour and Welfare. Byouin no heikinzaiinnnissuu-byoushou no shurui xnenjibetu. 2012. Available from: http: //www.mhlw.go.jp/toukei/youran/indexyk_2_2.html

[2] Ministry of Health, Labour and Welfare. Koukikoureisha nikakawaru sinryouhoushuu nitsuite. 2008. Available from: http://www. mhlw .go.jp/shingi/2009/12/dl/s1204-7a.pdf

[3] Medical Economics Division, Health Insurance Bureau, Ministry of Health, Labour and Welfare Ministry of Health, Labour and Welfare. Heisei24nenndo shinryouhoushuukaitei no gaiyou. 2012. Available from: http://www.mhlw.go.jp/bunya/iryouhoken/ iryouhoken15/dl/gaiyou_1.pdf

[4] Japan Nursing Association. Nursing white paper 2014. Japan Nursing Association Publishing Company, Tokyo; 2014. 23-32.

[5] Nagata S, Tomura H, Murashima S. Expansion of discharge planning system in Japan: comparison of results of a nationwide survey between 2001 and 2010. BMC Health Services Research. 2012; 12 237. PMid:22863296 http://dx.doi .org/10.1186/1472-696 3-12-237

[6] Sumi N. Taiinshien ga hitsuyouna kesu toha. Rinshoukango. 2010 36(1): 9-12.

[7] Tokyo Women's Medical University. Taiinchousei manyuaru (taiinsien nikansuru anketo houkokusho). 2010; 10-11. Available from: http://ir.twmu.ac.jp/dspace/bitstream/10470/1 8424/4/taiin_H21.pdf

[8] Rhudy L, Holland D, Bowles KH. Illuminating hospital discharge planning: staff nurse decision making. Applied Nursing Research 2010; 23(4): 198-206. PMid:21035029 http://dx.doi.org/10. 1016/j.apnr.2008.12.003

[9] Holland D, Knafl G, Bowles K. Targeting hospitalized patients for early discharge planning intervention. Journal of Clinical Nursing.
2013; 22: 2696-2703. PMid:22906077 http://dx.doi.org/10. $1111 / \mathrm{j} .1365-2702.2012 .04221 . \mathrm{x}$

[10] Domoto T, Takemura Y, Nagata S. Effects of a screening tool and conferences on nurses' discharge-planning ability in a hospital without a discharge-planning department. Clinical Nursing Studies. 2014; 2(3): 127-139. http://dx . doi .org/10.5430/cns . v2n3p127

[11] Young $S$. Teaching, learning, and assessment in higher education: using ICE to improve student learning. Proceedings of the Improving Student Learning Symposium. London, UK. 2005; 13: 105-115.

[12] Lai C, Nye H, Bookwalter T, et al. Postdischarge follow-up visits for medical and pharmacy students on an inpatient medicine clerkship. Society of Hospital Medicine. 2008; 3(1): 20-27. PMid:18257097 http://dx.doi.org/10.1002/jhm. 264

[13] Hall S, Schmidt K, Aagaard E. Toward safe hospital discharge: a transitions in care curriculum for medical students. Journal of General Internal Medicine. 2010; 25(8): 878-881. PMid:20443072 http://dx.doi.org/10.1007/s11606-010-1364-3

[14] Suzuki S, Nagata S, Zerwekh J, et al. Effects of a multi-method discharge planning educational program for medical staff nurses. Japan Journal of Nursing Science. 2012; 9(2): 201-215. PMid:23181889 http://dx.doi.org/10.1111/j.1742-7924.2011.00203.x

[15] Sumi N, Okuhara Y, Adachi T, et al. Validity of a revised screening tool for identifying patients in need of discharge planning at a university hospital. Journal of Comprehensive Nursing Research. 2007; 10(3): 53-64.

[16] Hashidate H, Shimada H, Shiomi T, et al. Measuring indoor lifespace mobility at home in older adults with difficulty to perform outdoor activities. Journal of Geriatric Physical Therapy. 2013; 36(3): 109-114. PMid:22976813 http://dx. doi .org/10.1519/JPT . 0 b013e31826e 7 d33 
[17] Popejoy LL. Complexity of family caregiving and discharge planning. Journal of Family Nursing. 2011; 17(1): 61-81. PMid:21343622 http://dx.doi.org/10.1177/1074840710394855

[18] Strivens E, Craig D. Managing dementia-related cognitive decline in patients and their caregivers. Reprinted From Australian Family Physician. 2014; 43(4): 170-174.

[19] Japan National Health Insurance Clinics and Hospitals Association. Kazokukaigosha no jittaito sienhousaku nikansuru chousakenkyuu jigyouhoukokusho. 2011; 28. Available from: http://www.koku shinkyo.or.jp/Portals/0/01

[20] Horiguchi K, Iwata N, Matsuda N. Classification of caregiving families according to the Family Caregivers' Appraisal Checklist. Kobe Journal of Medical Sciences. 2012; 58(5): 145-159.

[21] Yamashita CH, Correia GJ, Amendola F, et al. Social network of family caregivers of disabled and dependent patients. Revista da Escola de Enfermagem da USP. 2014; 48(Esp): 95-101. Available from: http://www.scielo.br/pdf/reeusp/v48nspe/0080-6 234-reeusp-48-esp-097.pdf
[22] Cobo CMS. The influence of institutionalization on the perception of autonomy and quality of life in old people. Revista da Escola de Enfermagem da USP. 2014; 48(6): 1011-1017. Available from: http://www.scielo.br/pdf/reeusp/v48n6/008 0-6234-reeusp-48-06-1013.pdf PMid:25626500 http://dx .doi.org/10.1590/S0080-623420140000700008

[23] Fritz D, Pitlick M. Evidence about the prevention and management of constipation: implications for comfort. Home Healthcare Nurse. 2012; 30(9): 533-540. PMid:23026989 http://dx.doi .org/10 . $1097 / \mathrm{NHH}$. Ob013e31826a676f

[24] Domoto T, Saneto M. Nursing students' assessment of paper patients for hospital discharge. Japanese Red Cross Hiroshima College Nursing. 2014; 14: 55-64.

[25] Okamoto R, Sakakibara C, Kohei Y, et al. Change in thoughts about the elderly people that gerontological nursing students hold: analysis of second and third year students. Bulletin of Hokkaido Bunkyo University. 2011; 35: 65-74. 